\title{
Iron Diazoalkane Chemistry: N-N Bond Hydrogenation and Intramolecular C-H Activation.
}

\author{
Supporting Information \\ Suzanne C. Bart, Amanda C. Bowman, Emil Lobkovsky, Paul J. Chirik* \\ Department of Chemistry and Chemical Biology, Baker Laboratory
}

Cornell University, Ithaca NY, USA 14853. Fax: 607-255-4137; Tel: 607-254-4538;

Email:pc92@cornell.edu 


\section{Table of Contents}

$\begin{array}{ll}\text { Experimental Procedures } & \text { S3 }\end{array}$

${ }^{1} \mathrm{H}$ NMR spectrum of $\mathbf{1 - \mathbf { N } _ { 2 }} \mathbf{C H S i M e}_{\mathbf{3}} \quad$ S8

Variable temperature ${ }^{1} \mathrm{H}$ NMR data for $\mathbf{1 - \mathbf { N } _ { 2 }} \mathbf{C H S i M e}_{3} \quad$ S9

$\begin{array}{ll}\text { Infrared spectrum of } 2 & \text { S10 }\end{array}$

$\begin{array}{ll}\text { References } & \text { S10 }\end{array}$ 


\section{Experimental Section}

General Considerations. All air- and moisture-sensitive manipulations were carried out using standard vacuum line, Schlenk and cannula techniques or in an MBraun inert atmosphere drybox containing an atmosphere of purified nitrogen. The MBraun drybox was equipped with a cold well designed for freezing samples in liquid nitrogen. Solvents for air- and moisture-sensitive manipulations were initially dried and deoxygenated using literature procedures. ${ }^{1}$ Argon and hydrogen gas were purchased from Airgas Incorporated and passed through a column containing manganese oxide supported on vermiculite and 4 $\AA$ molecular sieves before admission to the high vacuum line. Benzene- $d_{6}$ was purchased from Cambridge Isotope Laboratories and distilled from sodium metal under an atmosphere of argon and stored over $4 \AA$ molecular sieves or sodium metal. Trimethylsilyldiazomethane was purchased from Aldrich as a 1.0 M solution in hexanes and used as received. Anhydrous ammonia was purchased from Air Gas dried over $4 \AA$ molecular sieves and passed through a liquid nitrogen trap before use. Hydrazine was purchased from Acros and dried over $4 \AA$ molecular sieves before use. 1-( $\left.\mathbf{N}_{2}\right)_{2}{ }^{2}$ was prepared according to literature procedures.

${ }^{1} \mathrm{H}$ NMR spectra were recorded on Varian Mercury 300, Inova 400 and 500 spectrometers operating at 299.763, 399.780 and $500.62 \mathrm{MHz}$, respectively. All chemical shifts are reported relative to $\mathrm{SiMe}_{4}$ using ${ }^{1} \mathrm{H}$ (residual) chemical shifts of the solvent as a secondary standard. For paramagnetic molecules, the ${ }^{1} \mathrm{H}$ NMR data are reported with the chemical shift followed by the peak width at half height in Hertz or multiplicity, followed by integration value and where possible, peak assignment. For NMR experiments that are quantitative, an internal ferrocene standard was used. 
Single crystals suitable for X-ray diffraction were coated with polyisobutylene oil in a drybox and were quickly transferred to the goniometer head of a Siemens SMART CCD Area detector system equipped with a molybdenum X-ray tube $(\lambda=0.71073 \AA)$. Preliminary data revealed the crystal system. A hemisphere routine was used for data collection and determination of lattice constants. The space group was identified and the data were processed using the Bruker SAINT program and corrected for absorption using SADABS. The structures were solved using direct methods (SHELXS) completed by subsequent Fourier synthesis and refined by full-matrix least-squares procedures.

Preparation of $\left({ }^{\mathrm{iPr}} \mathrm{PDI}\right) \mathrm{Fe}\left(\mathrm{N}_{2} \mathbf{C H S i M e}\right)\left(\mathbf{1 - N _ { 2 }} \mathrm{CHSiMe}_{3}\right)$. A $20-\mathrm{mL}$ scintillation vial was charged with $0.030 \mathrm{~g}(0.051 \mathrm{mmol}) \mathbf{1}-\left(\mathbf{N}_{2}\right)_{2}$ and approximately $10 \mathrm{~mL}$ of diethyl forming a green solution. To the vial, $25 \mu \mathrm{L}(0.051 \mathrm{mmol})$ of trimethylsilyldiazomethane $(2 \mathrm{M}$ solution in hexanes) was added via microsyringe, resulting in vigorous bubbling and an immediate color change from green to purple-brown. The resulting reaction mixture was stirred for approximately five minutes and the volatiles were removed in vacuo yielding $0.031 \mathrm{~g}(94 \%)$ of a dark solid identified as $\mathbf{1}-\mathbf{N}_{2} \mathbf{C H S i M e}$. Analysis for $\mathrm{C}_{37} \mathrm{H}_{53} \mathrm{~N}_{5} \mathrm{SiFe}$ : Calc. C, 68.18; H, 8.20; N, 10.74. Found C, 68.49; H, 8.49; N, 10.33. ${ }^{~}{ }^{H}$ NMR (benzene$\left.d_{6}\right): \delta=-1.55\left(\mathrm{~s}, 6 \mathrm{H}, \mathrm{C}\left(\mathrm{CH}_{3}\right)\right),-0.86\left(\mathrm{~s}, 1 \mathrm{H}, \mathrm{N}=\mathrm{NCHSiMe}_{3}\right),-0.25\left(\mathrm{~s}, 9 \mathrm{H}, \mathrm{Si}\left(\mathrm{CH}_{3}\right)_{3}\right), 0.26$ (d, $\left.6.1 \mathrm{~Hz}, 12 \mathrm{H}, \mathrm{CH}\left(\mathrm{CH}_{3}\right)_{2}\right), 1.24\left(\mathrm{~d}, 6.8 \mathrm{~Hz}, 12 \mathrm{H}, \mathrm{CH}\left(\mathrm{CH}_{3}\right)_{2}\right), 3.18(\mathrm{q}, 6.1,4 \mathrm{H}$, $\left.\mathrm{CH}\left(\mathrm{CH}_{3}\right)_{2}\right), 7.39(\mathrm{~d}, 9.2 \mathrm{~Hz}, 4 \mathrm{H}, m$-aryl), $7.58(\mathrm{t}, 7.6 \mathrm{~Hz}, 2 \mathrm{H}, p$-aryl), $9.00(\mathrm{~m}, 3 \mathrm{H}, m, p$ pyridine). ${ }^{13} \mathrm{C}$ NMR (benzene- $\left.d_{6}\right): \delta=-0.28\left(\mathrm{Si}\left(\mathrm{CH}_{3}\right)_{3}, 23.70\left(\mathrm{CH}\left(\mathrm{CH}_{3}\right)_{2}\right), 24.19\right.$ $\left(\mathrm{CH}\left(\mathrm{CH}_{3}\right)_{2}\right), 26.90,29.13\left(\mathrm{CH}\left(\mathrm{CH}_{3}\right)_{2}\right), 30.61,78.94,108.93$ (m-pyridine ligand or $p$ - 
aryl), 124.082 (m-aryl), 126.14 (m- pyridine or $p$ - aryl), 140.33 (p-pyridine), 157.24, $158.32,158.99$.

\section{Preparation of $\left[\left(2,6-{ }^{i} \mathrm{Pr}_{2} \mathrm{C}_{6} \mathrm{H}_{3}\right)\left(\left(6-{ }^{\mathrm{i}} \mathrm{Pr}\right)\left(2-\left(\mathrm{C}=\mathrm{CH}_{2}\left(\mathrm{CH}_{3}\right)\right) \mathrm{C}_{6} \mathrm{H}_{3}\right) \mathrm{N}=\mathrm{CMe}\right)_{2} \mathrm{C}_{5} \mathrm{H}_{3} \mathrm{~N}\right] \mathrm{Fe}$ (2).} A 20-mL scintillation vial was charged with $0.030 \mathrm{~g}(0.048 \mathrm{mmol})$ of $\mathbf{1}-\mathbf{N}_{\mathbf{2}} \mathbf{C H S i M e} \mathbf{3}_{3}$ and approximately $10 \mathrm{~mL}$ of pentane to form a purple-brown solution. The solution was stirred for 48 hours eventually turning green. The volatiles were removed in vacuo to yield a green oil assigned as $\mathbf{2}$. Monitoring the reaction by ${ }^{1} \mathrm{H}$ NMR spectroscopy established quantitative formation of the NMR-silent $\mathbf{2}$. On a preparative scale, $\mathbf{2}$ was obtained in $94 \%$ yield as a green oil. Detection was made possible by addition of $\mathrm{H}_{2}$ followed by $\mathrm{N}_{2}$ to quantitiatively regenerate 1-( $\left.\mathbf{N}_{2}\right)_{2}$. Analysis for $\mathrm{C}_{33} \mathrm{H}_{41} \mathrm{~N}_{3} \mathrm{Fe}$ (2): Calc. C, 74.01; H, 7.72; N, 7.85. Found C, 74.22; H, 7.48; N, 7.63. Magnetic susceptibility for 2 (benzene- $d_{6}$ ): $\mu_{\text {eff }}=2.7 \mu_{\mathrm{B}}$. Treatment of a benzene- $d_{6}$ solution of $\mathbf{2}$ with water liberated free bis(imino)pyridine ligand with a dehydrogenated isopropyl group: ${ }^{1} \mathrm{H}$ NMR (benzene- $d_{6}$ ): $\delta=1.11-1.25\left(\mathrm{~m}, 18 \mathrm{H}, \mathrm{CHMe}\right.$ ), $1.99\left(\mathrm{~s}, 3 \mathrm{H}, \mathrm{CH}_{2}=\mathrm{CMe}\right), 2.23(\mathrm{~s}, 3 \mathrm{H}$, $\mathrm{N}=\mathrm{CMe}$ ), 2.30 (s, 3H, N=CMe), 2.85 (quint, 1H, CHMe), 2.91 (quint, 1H, CHMe), 3.05 (quint, $1 \mathrm{H}, \mathrm{CHMe}$ ), $4.93\left(\mathrm{~s}, 1 \mathrm{H}, \mathrm{CH}_{2}=\mathrm{CMe}\right.$ ), $5.06\left(\mathrm{~s}, 1 \mathrm{H}, \mathrm{CH}_{2}=\mathrm{CMe}\right.$ ), 7.05-7.23 (m, 6H, Ar), $7.28(\mathrm{t}, 1 \mathrm{H}$, p-pyridine $), 8.46(\mathrm{~d}, 1 \mathrm{H}$, m-pyridine $), 8.48$ (d, 1H, m-pyridine). Recrystallization of green 2 from pentane at $-35^{\circ} \mathrm{C}$ under an atmosphere of dinitrogen furnished a small amount of brown crystals over the course of weeks identified as $\mathbf{2 - \mathbf { N } _ { 2 }}$. IR (KBr): $v\left(\mathrm{~N}_{2}\right)=2090 \mathrm{~cm}^{-1}$. This material was further characterized by single crystal Xray diffraction. 
Preparation of $\left({ }^{\mathrm{iPr}} \mathbf{P D I}\right) \mathbf{F e}\left(\mathrm{NH}_{\mathbf{3}}\right)\left(\mathbf{1}-\mathbf{N H}_{\mathbf{3}}\right)$. A thick walled glass vessel was charged with $0.148 \mathrm{~g}(0.250 \mathrm{mmol}) \mathbf{1 -}\left(\mathbf{N}_{2}\right)_{2}$ and approximately $20 \mathrm{~mL}$ of pentane. The vessel was submerged in liquid nitrogen and evacuated on the vacuum line. At $-196{ }^{\circ} \mathrm{C}$, a slight excess ( $\sim 2$ equiv.) of $\mathrm{NH}_{3}$ was added. The resulting reaction mixture was warmed to room temperature and stirred for one hour, resulting in a color change from green to redbrown. The volatiles were removed in in vacuo to yield $0.107 \mathrm{~g}(75 \%)$ of a red-brown powder identified as 1- $\mathbf{N H}_{3}$. Analysis for $\mathrm{C}_{33} \mathrm{H}_{46} \mathrm{~N}_{4} \mathrm{Fe}$ : Calc. C, 71.50; H, 8.40; N, 10.10. Found C, 71.19; H, 8.65; N, 9.92. ${ }^{1} \mathrm{H}$ NMR (benzene- $\left.d_{6}\right): \delta=-5.83$ (s, 6H, C $(M e)$ ), -0.52 (d, $6.6 \mathrm{~Hz}, 12 \mathrm{H}, \mathrm{CHMe}$ ), 1.22 (d, $6.7 \mathrm{~Hz}, 12 \mathrm{H}, \mathrm{CHMe}$ ) 2.65 (q, $7.8 \mathrm{~Hz}, 4 \mathrm{H}, \mathrm{CHMe}$ ), $3.14\left(\mathrm{~s}, 3 \mathrm{H}, \mathrm{NH}_{3}\right), 7.23(\mathrm{~d}, 7.8 \mathrm{~Hz}, 4 \mathrm{H}, m$-aryl), $7.64(\mathrm{t}, 7.4 \mathrm{~Hz}, 2 \mathrm{H}, p$ - aryl), 8.70 (t, 8.4 $\mathrm{Hz}, 1 \mathrm{H}$, p-pyridine), $11.84\left(\mathrm{~d}, 8.0 \mathrm{~Hz}, 2 \mathrm{H}\right.$, m-pyridine). ${ }^{13} \mathrm{C}$ NMR (benzene- $\left.d_{6}\right): \delta=23.48$ $\left(\mathrm{CH}\left(\mathrm{CH}_{3}\right)_{2}\right), 23.96\left(\mathrm{CH}\left(\mathrm{CH}_{3}\right)_{2}\right), 28.25\left(\mathrm{CH}\left(\mathrm{CH}_{3}\right)_{2}\right), 38.90\left(\mathrm{~N}=\mathrm{CH}_{3}\right), 103.22$ (m-pyridine), 124.07 (m-aryl), 124.97 (p-aryl), 136.43 (p-pyridine), 138.73, 163.25, 164.15, 187.95. IR $(\mathrm{KBr}): v_{\mathrm{N}-\mathrm{H}}: 3340 \mathrm{~cm}^{-1}$.

Hydrogenation of 1- $\mathbf{N}_{2} \mathrm{CHSiMe}_{3}$ to yield 1- $\mathbf{N H}_{3}$. A thick walled glass vessel was charged with $0.020 \mathrm{~g}(0.034 \mathrm{mmol})$ of $\mathbf{1}-\mathbf{N}_{2} \mathbf{C H S i M e}_{3}$ and approximately $2 \mathrm{~mL}$ of benzene- $d_{6}$. The vessel was removed from the drybox, immediately submerged in liquid nitrogen and evacuated. One atmosphere of hydrogen was added at $-196{ }^{\circ} \mathrm{C}$, and the solution was warmed to room temperature. The resulting reaction mixture was stirred for 14 hours after which time a red-brown solution formed. Monitoring the progress of the reaction by ${ }^{1} \mathrm{H}$ NMR spectroscopy established quantitative conversion to 1-( $\left.\mathbf{N H}_{\mathbf{3}}\right)$ along with one equivalent of $\mathrm{SiMe}_{4}$. 
Toepler Pump Experiment for Reaction of $\left({ }^{\mathrm{iPr}} \mathrm{PDI}\right) \mathrm{Fe}\left(\mathrm{N}_{2}\right)_{2}$ and $\mathrm{H}_{2} \mathrm{~N}-\mathrm{NH}_{2}$. A small glass ampoule was charged with $3.7 \mu \mathrm{L}(0.132 \mathrm{mmol})$ of $\mathrm{H}_{2} \mathrm{~N}-\mathrm{NH}_{2}$ and approximately 0.5 $\mathrm{mL}$ toluene, and flame-sealed under vacuum at $-78^{\circ} \mathrm{C}$. A thick-walled glass vessel was charged with $0.039 \mathrm{~g}(0.066 \mathrm{mmol})$ of $\left({ }^{\mathrm{iPr}} \mathrm{PDI}\right) \mathrm{Fe}\left(\mathrm{N}_{2}\right)_{2}$, the glass ampoule and a stir bar. Approximately $15 \mathrm{~mL}$ of diethyl ether was vacuum-transferred into the vessel at $-78{ }^{\circ} \mathrm{C}$. The reaction mixture was warmed to room temperature and the glass ampoule inside the vessel was broken with stirring. Immediately upon mixing, a dark brown solution formed, liberating a mixture of dihydrogen and dinitrogen. The gas mixture was collected with a Toepler pump into a volume of $43.7 \mathrm{~mL}$. After $1.5 \mathrm{~h}, 52$ Torr (1.9 eq.) of gas was collected. The gas mixture was cycled through a burn tube over $0.5 \mathrm{~h} ; 14$ Torr ( 0.5 eq.) of dihydrogen was burned, and 38 Torr (1.4 eq.) of dinitrogen was recollected over $1 \mathrm{~h}$. A ${ }^{1} \mathrm{H}$ NMR spectrum of the dark brown solid remaining in the vessel confirmed formation

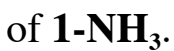




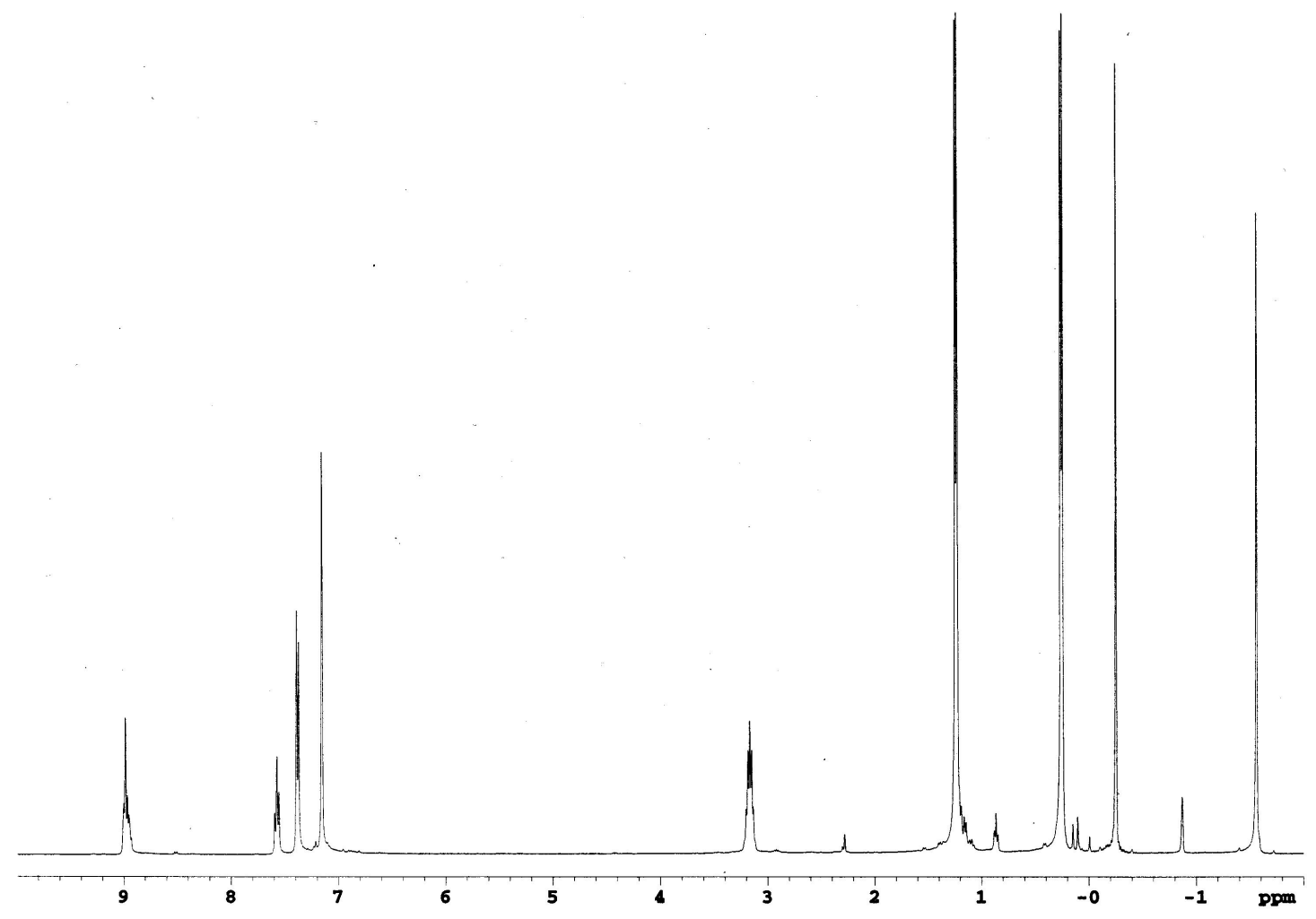

Figure S1. ${ }^{1} \mathrm{H}$ NMR spectrum of $\mathbf{1 - \mathbf { N } _ { 2 }} \mathbf{C H S i M e} \mathbf{e}_{3}$ recorded in benzene- $d_{6}$ at $23{ }^{\circ} \mathrm{C}$. 


\section{$\mathrm{Si}\left(\mathrm{CH}_{3}\right)_{3}$}
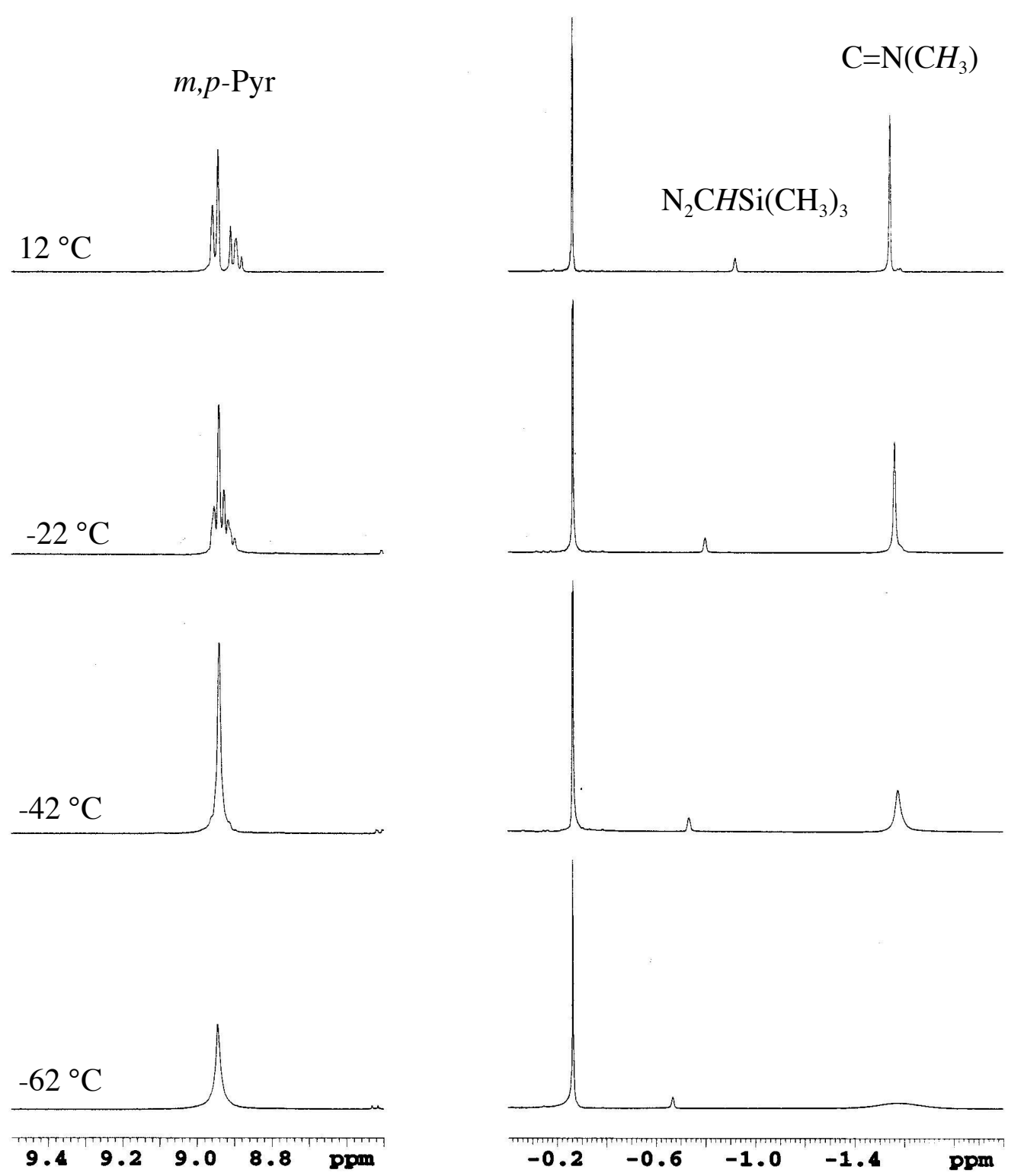

Figure S2. Variable temperature ${ }^{1} \mathrm{H}$ NMR spectra of $\mathbf{1}-\mathbf{N}_{2} \mathbf{C H S i M e} \mathbf{e}_{3}$ recorded in toluene- $d_{8}$. 


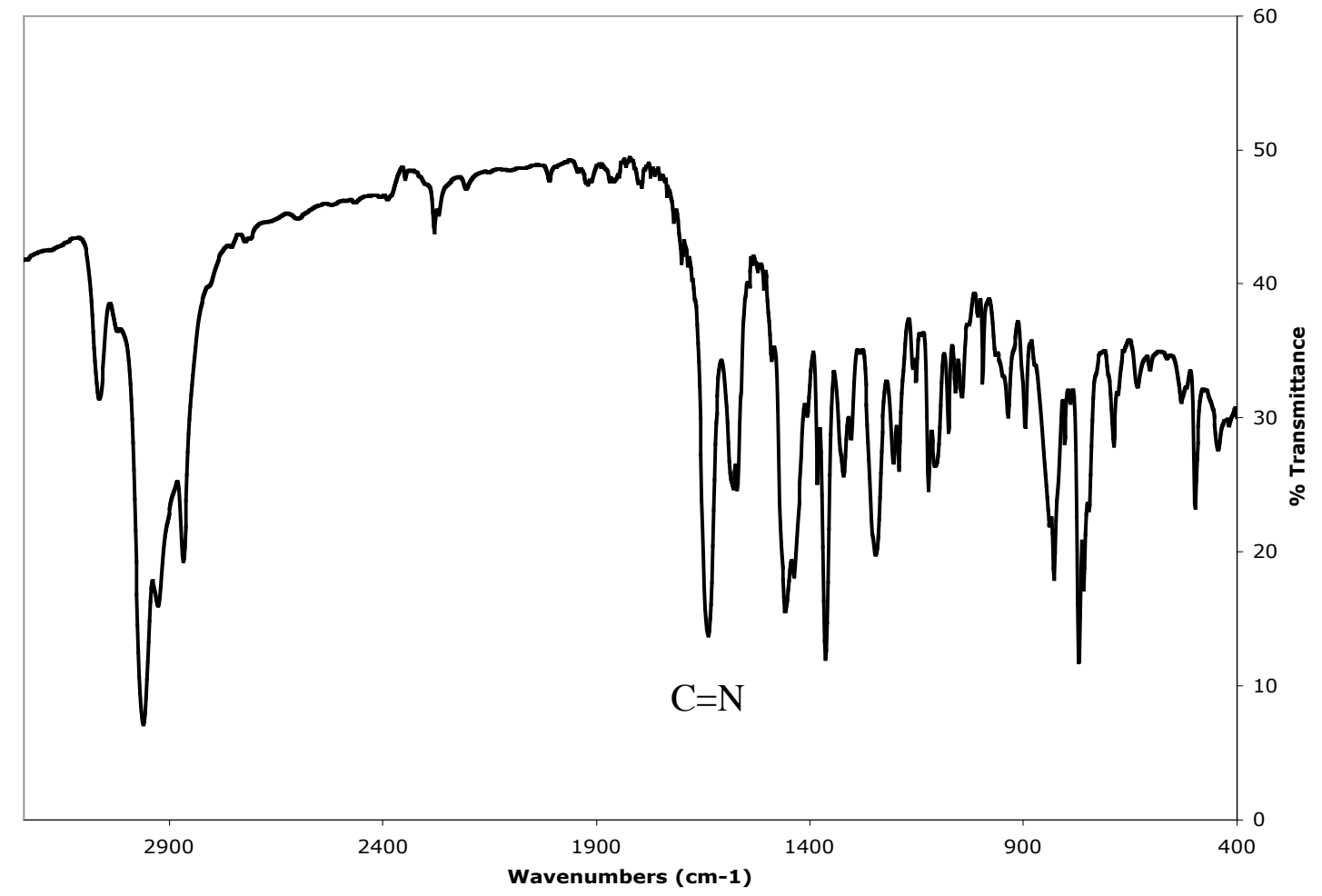

Figure S3. Infrared spectrum of $\mathbf{2}$ recorded in $\mathrm{KBr}$.

\section{References.}

${ }^{1}$ Pangborn, A. B.; Giardello, M. A.; Grubbs, R. H.; Rosen, R. K.; Timmers, F. J. Organometallics 1996, 15, 1518.

${ }^{2}$ Bart, S. C.; Lobkovsky, E.; Chirik, P. J. J. Am. Chem. Soc. 2004, 126, 13794. 